\title{
DEVELOPING WORD BUBBLE GAME TO TEACH VOCABULARY FOR ELEMENTARY SCHOOL IN THE ACADEMIC YEAR 2017/2018
}

\author{
Abdullah Farih; Wahyu Maulidah \\ abdullahfarih@unisla.ac.id; winda_maulidah58@yahoo.co.id \\ Pendidikan Bahasa Inggris, FKIP, Universitas Islam Lamongan
}

\begin{abstract}
The research aims at developing vocabulary materials based on Word Bubble Games for the students of Elementary School students'. The main purpose of this study is to help the English teachers to create fun activities in teaching English by introducing traditional Word Bubble games to the students. To reach the purpose of the study, the researcher employed Research and Development method (R\&D) and adapted ADDIE' model. The researcher used three instruments to obtain the data such as interview, questionnaires and observation. The obtained data will be classified based on the instrument used. To show the results, the researcher explained them in quantitative and qualitative approach. The results show that most of fifth grade students of MI Fathul Huda give a good response toward the developed games. In addition, the experts gave an excellent judgment to the developed materials. After finishing all the stages, the researcher finally provided prototype product. The prototype product is a handbook for the teachers to teach vocabulary. The book entitled "Gladhi English" which comprises of six lessons and ten games which have been modified in order to be applicable in teaching vocabulary.
\end{abstract}

Key words: Word Bubble Games, Teaching Vocabulary

\section{INTRODUCTION}

Learning English in early ages has advantages from both biological and psychological point of view. Based on those advantages, Indonesian government through 1994's Primary School Curriculum has introduced English as "local content", starting from grade four at primary school. In ten years of its application, English in primary school still has a number of problems that need solutions.

The failure of English teaching in Indonesia has made policy makers to always make changes. One of the changes made is to start introducing English at an earlier age, starting from fourth grade of elementary school, although still limited to local content in the 1994 Basic Education Curriculum. The main purpose of introducing English at an earlier age is to improve the quality of output and grant more input (Huda, 1999; Sutarsyah 2004). The rationale behind this change is that language learning in children has several advantages. Age factor of onset (AO) is one of the determinants of language learning success. Learning the language will get perfection when it starts at the age before puberty because at this age biologically the brain has a high level of elasticity that allows one to learn a language faster (Lennerberg in Sujana, 2001; Khrasen in Sutarsyah, 2004). Besides learning language in childhood will be more successful because psychologically children are free from the shame and fear wrong as experienced adult language learners.

Apparently departing from this superiority The Government of Indonesia through the Basic Education Curriculum 1994 started introducing English at an earlier age, starting from the fourth grade of elementary school (at age 10). Although as a local content, schools and parents are very enthusiastic about welcoming the idea of early English. This is evidenced by the 
number of primary schools that began to provide English as local content (see Kismadi, 2004, Luciana, 2004, Sutarsyah, 2004), although in many schools it faces obstacles such as the readiness of syllabus, material, teachers, teaching methods and others.

But what policy makers and practitioners need to realize in the field is that learning a second language naturally (acquisition) is different from learning a formal language (learning) in many ways. Language perfection is relatively easier to achieve in an informal (natural) context because of the many supporting aspects such as setting, modeling, language use, and the desire to convey a message (the need to communicate). In other words, the advantages mentioned above will not contribute much if the instructional program is not carefully designed. In this case, teacher factors, materials, facilities, learning settings play a significant role in achieving language perfection and should be tailored to the learning characteristics of the child's age. Pronunciation errors, for example, will have a major effect on the child's language development and the errors tend to be fossilized, making it difficult to change at the next level.

Teaching vocabulary to the elementary school students is not an easy task, it requires a lot of creativity. It is important to make students interest in learning vocabularies. There are several possible ways to introduce the vocabulary of a foreign language to students. To attract the students' motivation in learning vocabulary especially young learners, the teachers should use a variety of techniques or strategy and also using media.

Learning media is a tool that can facilitate the achievement of learning objectives. The use of instructional media is realized by educational practitioners are very helpful in the learning process activities both inside and outside the classroom, especially improving student learning outcomes. According to Nana Sudjana and Ahmad Rivai (2005: 2), teaching media can enhance students' learning process which in turn is expected to enhance the achievement of learning achievement.

Vocabulary presented in a familiar context and systemized manner with visual support seems important for memorization; using the senses, games, songs, stories and rhymes are effective ways of practicing language (Brewster etalinDochart, 2010:101). It means that we must choose the strategy or media that appropriate to use in teaching vocabulary.

Sanchez et al (2007:50) state that a game is considered a valuable technique, which includes three principle elements: competition, rule(s) and enjoyment, which should be well established by a teachinglearning objective. Students usually get bored in doing tasks from the teachers which only prefer at monotonous activity. In this case, games are added as technique which is not only served as a musing activities but also as a technique to overcome the students' boredom in doing tasks. Introducing games in languagelearning class may create fun activities which can help students to have an interaction with their friends. Kiryk (2010:4) states that games are considered as fun activities that promote interaction, thinking, learning, and problem solving. Everyone believes that the main goal of teaching language is to get the students have good communicative skill. Good communicative skill is proven when students are able to express their thought and ideas. Al-Nafisah (2012:22) defines that games are activities which can increase students-talk and promote interaction among students for communicative purpose. From the statements stated by some expert, there searcher concludes that games are considered as activities which are able to applying language-learning classroom and 
decrease the students' boredom during teaching and learning activity.

Thegamesthat canbeusedto teachvocabularyareMedia Card English Vocabulary. This media contains an alphabet card and a picture card where expected to help students in the mastery of English vocabulary, so as to achieve good results and provide convenience to teachers in an effort to provide English language material. In addition, the researchers also hope with the Media Card English Vocabulary can provide a medium of learning in MI / SD that can be used by teachers in learning English vocabulary and can be a method of learning in learning English vocabulary for learning becomes more interesting. Therefore, researchers do the research with the title "Developing Word Bubble Game to Teach Vocabulary for Elementary School in The Academic Year 2017/2018".

\section{METHOD}

The method used in this research is the method of research and development, and the type of product produced is learning media in the form of handbook for the teacher and vocabulary game "Word Bubble Games" which in the form of alphabet and picture cards. The development model in this research is using Analysis-Design-DevelopmentImplementation-Evaluation (ADDIE) model. Appears in year1990s developed by Reiser and Mollenda. This model was chosen because the ADDIE model is often used to describe a systematic approach to instructional development. In addition, the ADDIE model is a learning model that is general and appropriate to be used for development research. When used in development, this process is considered sequential but also interactive (Mollenda, 2003), where the evaluation of each stage can lead to the development of learning to the previous stage. The end result of a stage is the starting product for the next stage.

Product trials in this development study include: (1) Experimental design, (2) Test subjects, (3) Types of data, (4) Data collection instruments, and (5) Data analysis techniques. These trials will be conducted in several stages: a) review by the content specialist, b) review of design and learning media, c) small group test, and 6) large group test. The subjects tested in this research and development were reviewed by 1) content, design \& media experts, 2) small group test, this test numbered 12 students. 4) Large group trials, samples taken in one class $( \pm 26$ students). The instruments used to collect data in this research are questionnaires, interviews and observations. Questionnaires were used to collect the results of the review of experts, small groups (K-12), large groups and assessment of subject teachers. Interviews were used to collect "need analysis" data on teachers and students. While the observation is used to find out the results of trials in small and large groups.

There will be two types of method in presenting data analysis. They are quantitative data and qualitative data. Quantitative data will be presented in the form of number and qualitative data will be covered descriptively in the form of sentence. The data analysis will be explained in each step.In this study using descriptive statistical data analysis techniques, scores obtained from the observation, validation of media experts and material experts then converted into qualitative data using Likert scale, while the teacher questionnaire was converted by using Guttman scale. Next the questionnaire needs analysis and try out students, the researchers will count them in the form of percentage. 


\section{DISCUSSION}

The products produced in this study are learning media in the form of handbook for the teacher and vocabulary games "Word Bubble Games" which the form of alphabet and picture cards. The development of learning media to introduce English vocabulary in this research uses ADDIE research and development model which includes 5 stages, namely Analysis, Design, Develop, Implement, and Evaluation.

\section{Phase of Analysis}

At this stage investigator conducted an analysis by interviewing the English teacher of fifth grade of MI Fathul Huda. Aspects of needs analysis obtained include (a) analysis of the curriculum, (b) analysis of the media, and (c) analysis of the material.

\section{a. Analysis of Curriculum}

Interview results indicate that in general the English curriculum in fifth grade of MI Fathul Huda still use School Based Curriculum (SBC). Learning English in fifth grade of MI Fathul Huda held once a week and tailored to the learning theme. Based on that data, researchers developed a product with reference to the opinion of suharti and Suardiman (2010: 84), who said that learning English in children, especially upper class in elementary school has the main goal is that children like to speak English.

\section{b. Analysis of Media}

Analysis of media study includes need analysis, analysis of the characteristics of children, and utilization of instructional media to introduce the English vocabulary in elementary school especially fifth grade of MI Fathul Huda. The results of the needs analysis data showed that the implementation of learning English in MI Fathul Huda is still limited to the introduction of English vocabulary through habituation or demonstration by teachers.

c. Analysis of Content

Analysis of material is done by outlining the purpose of learning English in primary schools associated with the principles of language learning and developmental characteristics of children aged $10-12$ years.

The themes of English learning developed in this media which are Part of Body, Transportation, Profession, Things at School, Telling Time and My Family. The above material was developed into some part of learning media, there are picture card, alphabet card, and handbook for teachers.

\section{Phase of Design}

At the design phase contains instructional media framework consisting of picture card, alphabet card, and handbook for teacher. The material English vocabulary that is inserted into the picture cards, the alphabet cards and handbooks for teachers is English vocabulary, amounting to 138 , divided into six themes, either on handbooks teacher's Indonesian vocabulary is added to provide the knowledge for teachers who do not know the meaning of specific vocabulary in English.

\section{Phase of Develop}

This phase used in the development of picture cards, alphabet cards and handbook for teachers. These picture and alphabet cards done manually and digitally. Manual workmanship done by hand, while the digital manufacturing is done by using graphic design Corel Draw applications. Font used in this card is Monotype Corsiva. While, Handbook for teachers is done digitally by using graphic design Corel Draw applications. In this stage of development also includes the validation stage of material and media expert and revision of the first and second stage before the product is tested. For the first stage from material expert the product 
gets 3.9 and media expert 3.98 score. It means when seen by quantitative to qualitative data conversion, then the media that developed criteria "Good". While for the second stage from material expert the product gets 4.8 and media expert 4.3 score. It means when seen by quantitative to qualitative data conversion, then the media that developed criteria "Excellent".

\section{Phase of Implement}

This implementation stage includes trial usage and application of Word bubble Game media. Small group trials were conducted for 12 students of fifth grade of MI Fathul Huda taken at random. After the students have tested their product will fill out a response questionnaire where previously they also fill the questionnaire need analysis. The results of these can be seen comparison of student learning outcomes with or not using the media. In order for this media to be more accurate look more improve learning outcomes, it will be compared with large group trials conducted to all of student of fifth grade of MI Fathul Huda, amounting to 26 students. During the trial the researchers also used observations where sheet observation is used to load a feasibility assessment of the media from the aspect of activity or participation of children, child's interest, and ease of children using the media. Observations show that the child's responses to the media to get a score of 4.48 with the criteria of "Excellent" for Small group and 4.74 with the criteria of "Excellent" for Large group trials. For Assessment of teacher the media developed that shows scores 100.00 with the criteria of "Meet the feasibility aspect". 5. Evaluate

This stage is done since the researchers need analysis (analysis) to arrive at the stage (implementation). Evaluation at the designing stage of the product is done by considering the media of learning in the field and good

Developing Word Bubble Game to Teach Vocabulary for Elementary School in The Academic Year $2017 / 2018$ theoretical learning media requirements. While the stage of product development is done by reviewing inputs that have been given by media experts and material experts. Furthermore, researchers make improvements on these inputs until the media is ready to be tested.

\section{CONCLUSION AND SUGGESTION}

From the discussion it can be conclude that the development of instructional media Word Bubble Games worthy used to introduce the English vocabulary in the fifth grade of MI Fathul Huda based assessment materials experts, media specialists and teacher ratings MI stating the media's definition of "Eligible", the results of student responses to trials small groups and large groups indicate the category of "Enjoy and interest in playing These games". While the results of observations on the implementation of the media in both groups of the trial indicate the criteria of "Good". This suggests that learning media Word Bubble Games decent used to introduce and effective in improving students' English vocabulary fifth grade of MI Fathul Huda.

The writer suggests that any teacher who intends to apply teaching vocabulary using Word Bubble game especially for Elementary school effectively used when the teachers are able to speak English Well and able to present variations of learning in the classroom through the media.

\section{REFERENCES}

Al-Nafisah, I.K. 2012. Utilization of Instructional Games in EFL Teaching: A Case Study of Saudi Intermediate Schools, vol. 3 (2228),

(Online), (jeteraps.scholarlinkresearch.org), Retrieve on January, $1^{\text {th }} 2018$.

Anyaegbu, R., et al. 2012. Serious Game Motivation inanEfl Classroom in 
Chinese Primary School. Tojet, Turkey.

Arsyad, Azhar. 2011. Media Pembelajaran. Jakarta: PT. Raja GrafindoPersada.

Branch, Robert Maribe. 2009. Instructional Design: The ADDIE Approach. New York: Springer Science \& Business Media, LLC.

Byrne, Donn, 1986.Teaching Oral English. London and New York: Longman.

Cahyono, Bambang and

Kusumaningrum, Shirly. 2011.

Practical Techniques for English

Langugae Teaching. Malang: State

University of Malang Press.

Christiana, E., et al. 2014. The Implementation of The Modified Traditional Hop-Scotch Game In Group Counseling To Improve Students' Social Interaction Ability In Class Vii-A MtsNegeriTulungagung, 4, 1-10, (Online), (http://ejournal.unesa.ac.id). Retrieveon January, $1^{\text {th }} 2018$.

Hong, Lin, 2002. "Using games in teaching English to young children" in ELT Journal, Vol. 8, No. 8.

Jeffcoate, Robert, 1992. Starting English Teaching. London: Routledge.

Kiryk, A. 2010. Using Games in A Foreign Language Classroom, (Online), (http://digitalcollections.sit.edu/ipp _collection), Retrieve on January, $1^{\text {th }} 2018$.

Mardani. 2014. Journal Student, (Online), (http://journal.student.uny.ac.i d/ojs/index.php/elt/article/view 15278), accessed on January, $1^{\text {th }} 2018$.
Muhammad. 2015. Pengembangan Media Belajar,

(Online), (https://media.neliti.com/media/publi cations/191533-ID-fun-lyrics-flpengembangan-media-belajar.pdf), accessed on January, $1^{\text {th }} 2018$.

Ments, M. 1993. The Effective Use of a Role-Play: A Handbook for Teachers and Trainers. London: Kogan Page.

Nababan, Elysabeth.2015. Improving students' vocabulary through a smartphone Application, Learn English with music songs. Unpublished thesis North Sumatera: FKIP University of North Sumatera.

Okoń, Wincenty, 1997. Zabawa a rzeczywistość. Warszawa: WSiP.

Pargito. 2010. Penelitian dan Pengembangan Bidang Pendidikan. Universitas Lampung: Program Pasca Sarjana Pendidikan IPS.

Prawiradilaga, Dewi Salma. (2008). Prinsip desain pembelajaran. Jakarta: Kencana Prenada Media Group.

Rafidah. 2016. World Scientific News, (Online), (http://www.worldscientificnews.co $\mathrm{m} / \mathrm{wp}-$ content/uploads/2016/01/WSN-5322016-67-109-1.pdf), accessed on January, $1^{\text {th }} 2018$.

Riduwan, 2015. Cover, (Online), (http://repo.iaintulungagung.ac.id/3059/1/COVER .pdf), accessed on January, $1^{\text {th }} 2018$.

Samsuri.1980. Memahami Bahasa secara Ilmiah. Cetakan ke-2. Jakarta: Erlangga.

Sanchez, M.M.M., et al. 2007. Interactive Games in the Teaching - Learning 
Process of a Foreign Language, 4, 46-47.

Sanjana, Wina. 2012. Perencanaan dan Desain Sistem Pembelajaran. Cetakan ke-5. Jakarta: Kencana Prenada Media Grup.

Siek-Piskozub Teresa, 1995. Gry, Zabawy i Symulacje w Procesie Glottody daktycznym, Poznań: WydawnictwoNaukowe UAM.

StojkoviĤ, M.K., et al. (2011). Reasons for Using or Avoiding Games in an EFL Classroom. 1st International Conference on Foreign Language Teaching and Applied Linguistics May 5-7 2011 Sarajevo. Retrieve on January, $1^{\text {th }} 2018$.

Sugiyono. 2013. Metode penelitian pendidikan. Bandung: Alfabeta.

Toth, M. 1995. Children's games. Oxford: Heinemann Publishers. 